\title{
Wielcy wiarołomcy
}

\section{DOI 10.35757/CIV.2015.17.18}

Stanisław Koper, Wielcy zdrajcy. Od Piastów do PRL, Bellona, Warszawa 2012, ss. 351; Pedro Pablo G. May, Wielcy zdrajcy $w$ dziejach świata. Od starożytności po nasze czasy, przekład S. Bończyk, Bellona, Warszawa 2012, ss. 238.

W roku 2012 nakładem wydawnictwa Bellona ukazały się dwie książki podejmujacce tematykę zdrady. Pierwsza pozycja to Wielcy $z$ drajcy $w$ dziejach świata pióra Pedra Pabla G. Maya, Stanisław Koper jest autorem drugiej - Wielcy zdrajcy. Od Piastów do PRL. Obaj badacze sa znanymi popularyzatorami historii. May wśród hispanojęzycznych czytelników zdobył sławę dzięki pracom poświęconym teoriom spiskowym. W publikacjach Kopra szczególne miejsce zajmuja badania nad międzywojniem oraz obyczajowościa w XIX stuleciu. Autor szerszemu gronu odbiorców znany jest także ze swej publicystyki prasowej.

Tym, co łączy obie książki, jest nie tylko podjęty temat zdrady, lecz także sposób jego realizacji. W obu publikacjach porządek chronologiczny wyznacza układ rozdziałów. Przegląd zdrajców u Maya został poprzedzony kulturoznawczymi rozważaniami nad aktem zdrady jako takim, podczas gdy Koper we wstępie daje wyraz kilku refleksjom ogólnym. Każdemu $z$ bohaterów $\mathrm{w}$ obu pracach został poświęcony osobny rozdział, te $\mathrm{w}$ istocie stanowia samodzielne artykuły. Układ ten pozwala czytelnikowi na znaczna dowolność lektury. Omawiane publikacje maja charakter popularnonaukowy, sa raczej powtórkami z lekcji historii niż systematycznymi badaniami. Odnajdziemy w nich przystępnie opowiedziane dzieje zdrad, które obaj pisarze często okraszaja ciekawostkami. 
Ramy czasowe autorzy zawarli już w podtytułach. I tak May swoja pracę poświęca zdradom w dziejach świata od starożytności po czasy współczesne, choć skupia się przede wszystkim na przedstawicielach Starego Kontynentu. Autor opisuje tylko postacie historyczne. Publikację zamyka opowieść o wydarzeniach z 11 września 2001 roku. Koper z kolei zawęża przedmiot swoich rozważań do wybranych postaci rodzimych zdrajców. I w jego wypadku ramy czasowe publikacji pozostaja imponujące, gdyż zgodnie $z$ podtytułem sięgaja one od Piastów do PRL. Mamy zatem do czynienia $z$ przeglądem bohaterów wiarołomstwa w całej historii Polski. Omawiana pozycja zawiera dwanaście rozdziałów, $z$ których każdy poświęcony jest jednej postaci. Rozdziały składaja się z kilku krótkich części, w których autor opisuje akt zdrady wraz $z$ przedstawieniem tła wydarzeń. W swych rozważaniach historyk koncentruje się przede wszystkim na kwestii patriotyzmu, choć nie unika także problematyki religijnej i obyczajowej, zapewniajacc, że starał się „przedstawić najciekawsze postacie, a na pewno najmniej jednoznaczne" (s. 8).

Poczet wielkich zdrajców przedstawiony przez obu badaczy dobrany został według subiektywnego kryterium autorskiego. Kryterium selekcji opisywanych postaci nie była wielkość realnie dokonanych zdrad, lecz stopień ich społecznej stygmatyzacji. Bohaterami ksiażek sa zatem postacie historyczne, którym przypisuje się dokonanie aktów zdradzieckich.

$\mathrm{Na}$ klucz doboru postaci $\mathrm{w}$ recenzowanych pozycjach duży wpływ miał społeczny odbiór opisywanych bohaterów. Przez wieki kolejne postacie, tak jak Judasz, ulegały stygmatyzacji. Ze względu na szerokie ramy czasowe obu pozycji można wyodrębnić dwa modele mitologizacji zdrajców.

Pierwszy model to bohaterowie homogeniczni. Charakteryzuja się oni tym, że zdrada, której się dopuścili, całkowicie zdominowała ich biografię, często też dokonany przez nich czyn łączy się $z$ jakimś ważnym wydarzeniem. Model ten jest znamienny dla postaci odległych nam czasowo, gdyż to właśnie upływający czas doprowadził 
do zaniku tła, pozostawiając tylko wiodącą kwestię wiarołomstwa. Za sztandarowy przykład takiego rodzaju zdrajców możemy uznać Brutusa. Zdrada Cezara jest największym tego typu występkiem świata starożytnego, dodatkowo jej wydźwięk wzmocniony został przez Dantego. May w swojej publikacji na jej tle przedstawia tak$\dot{z}$ e starożytny Rzym jako miasto ufundowane na zdradzie. Warto zauważyć, że już w micie założycielskim mamy do czynienia $z$ serią aktów wiarołomstwa, dzieje kolejnych Cezarów pokazuja zaś, że zdrady i intrygi stanowiły droge zdobywania i utraty władzy. Historie te wskazuja, że dla Rzymian zdrada była niemal polityczna tradycja. To w tym mieście doszło do aktu zdrady najbardziej znanego w historii zachodniej kultury politycznej. W idy marcowe 44 roku dwaj spiskowcy, Brutus i Kasjusz, przeprowadzili zamach na Juliusza Cezara. Jak głosi tradycja, około pięćdziesięciu senatorów zadało Cezarowi łącznie dwadzieścia trzy ciosy sztyletem, a dopiero ostatni, wymierzony przez adoptowanego syna władcy - Brutusa, okazał się śmiertelny.

Kolejna zdrada pokazana w książce Maya, która weszła do kanonu nie ze względu na swoją wagę, lecz na fakt, że spowodowała ważne procesy w ładzie wyznaniowym, jest historia Henryka VIII. Król ów znany był $z$ zamiłowania do uciech cielesnych oraz posiadania licznych kochanek. Ten rozpustny władca na skutek braku męskiego potomka oraz ciagłych trudności $z$ otrzymaniem ze Stolicy Apostolskiej kolejnych unieważnień małżeństwa ogłosił się głowa Kościoła w Anglii. Zasłyną sześcioma małżeństwami oraz skazaniem niektórych ze swych żon na ścięcie. Na ironię zakrawa fakt, że ulubionym zarzutem, jaki król stawiał współmałżonkom podczas spraw rozwodowych, było właśnie cudzołóstwo. Koronnym przykładem postaci jednorodnej, której czyn został zmitologizowany, jest Guy Fawkes - bohater spisku prochowego. Grupa angielskich katolików zawiązała spisek, którego celem było wysadzenie pałacu westminsterskiego, a tym samym uśmiercenie zebranych tam przedstawicieli obu izb wraz $z$ protestanckim królem Jakubem I. W nocy z 4 na 5 listopada 1605 roku w pod- 
ziemiach parlamentu odnaleziono Guya Fawkesa oraz trzydzieści sześć beczek prochu przygotowanych do detonacji. Fawkesa oraz siedmiu innych spiskowców skazano na śmierć przez powieszenie i poćwiartowanie, co było obowiąująca wówczas w Anglii kara za zdradę stanu. W Wielkiej Brytanii spisek prochowy jest symbolem największej zdrady, dlatego co roku 5 listopada obchodzone sa upamiętniające go uroczystości. W tym kontekście na uwage zasługuje także postać Stanisława Szczęsnego Potockiego, jednego $z$ głównych uczestników konfederacji targowickiej. Właśnie to wydarzenie stało się w Polsce synonimem zdrady narodowej. Uczestnicy konfederacji przyczynili się do zdrady kraju, występując przeciw ustaleniom Sejmu Czteroletniego, w tym Konstytucji 3 maja. Potocki tak jak większość stronnictwa magnackiego uznał konstytucję za zamach na swoje prawa. Znalazł się w tej grupie, która na wieść o rządowych zmianach wyruszyła na sąsiednie dwory $z$ prośbą o interwencję w Polsce. Sam Szczęsny wyjechał do Jass, gdzie chciał zabiegać o poparcie u faworyta carycy - księcia Grzegorza Potiomkina. Nie mógł wiedzieć, że ten właśnie zmarł. Jednak przyszłym zdrajcom pomógł generał Szymon Kossakowski i to dzięki jego wstawiennictwu magnaci uzyskali wpływy na dworze petersburskim. Na żądanie prawdziwych patriotów, bo takie o sobie mieli mniemanie, caryca zdecydowała się na interwencje rosyjską w Polsce. Szczęsny Potocki nie uległ błaganiom kuzynów, którzy opowiadali się za konstytucją. Wskutek działan Potockiego Polska zniknęła $z$ mapy Europy, a on sam zapisał się w historii kraju jako jeden $z$ trzech zdrajców, którzy założyli swoje pieczęcie pod aktem największej zdrady narodowej. Koper tak ocenia postawę szlachcica: „W ciagu kilku lat magnat zaprzedał się Rosjanom, uważając oczywiście, że robi to dla dobra Rzeczypospolitej. Ograniczenie umysłowe Potockiego było jednak na tyle poważne, że faktycznie chyba nie odróżniał służenia interesom carycy od patriotyzmu" (s. 160).

Drugi model mitologizacji zdrajców to bohaterowie heterogeniczni, ich postrzeganie nie jest jednowymiarowe, a zdrada, której się 
dopuścili, często bywa przedmiotem sporu. Przeważnie ich czyny możemy interpretować na dwa sposoby. Bywa, że dla jednej grupy sa oni zdrajcami, dla drugiej zaś ich czyny sa bohaterskie. Takie kontrowersje budzi postać Jakuba Szeli przedstawionego $\mathrm{w}$ tekście Kopra. Szela był jednym $\mathrm{z}$ przywódców antyszlacheckich powstań chłopskich w Galicji. Doczekał się dwóch skrajnych legend - dla szlachciców był czarnym charakterem, chłopi zaś gloryfikowali jego czyny. W PRL przedstawiano go jako przywódcę powodowanego świadomością klasową. Według autora omawianej pozycji, był on sadystycznym analfabeta, który został wykorzystany przez władze austriackie. Podobny rozdźwięk budzi Feliks Dzierżyński - zdrajca dla większości Polaków, a dla Rosjan bohater jako jeden $z$ twórców państwa radzieckiego. Historycy jednomyślnie przyznają, że Dzierżyński stworzył trzy perfekcyjnie działające instytucje: służby specjalne, transport kolejowy i sierocińce. Jako dowódca tych pierwszych ma na sumieniu setki tysięcy ofiar. Był patologicznym sadysta, wedle jego słów, „dla aresztowanych nie potrzeba czterech ścian więzienia, gdyż wystarczy tylko jedna - do egzekucji”. Dzierżyński wychował bolszewików czekisów, którzy byli ślepymi wykonawcami woli partii. Czeka, która dowodził, miała prawo dokonywać egzekucji na „aktywnych kontrrewolucjonistach" bez wyroku sądu. Była to budząca powszechna grozę i nieznająca litości służba - taka jak jej przywódca. Czeka przeszła do historii jako symbol terroru, a sam Dzierżyński zyskał przez to miano Krwawego Feliksa czy też Czerwonego Kata. Co ciekawe, jednocześnie w jego biografii odnajdziemy wiele przejawów postawy propolskiej. O tym, jak niejednoznaczna postacią był Dzierżyński, świadcza liczne świadectwa na jego temat, które wraz z komentarzem historycznym zebrała Sylwia Frołow w wydanej niedawno biografii intymnej Żelaznego Feliksa.

Przykładem bohatera heterogenicznego jest przywołany przez Maya Ulisses. Mimo że jest on dziś znany bardziej jako waleczny i dobry król Itaki niż wiarołomca. Fortel, którego się dopuścił, zdobywając Troję, nie tylko sprowadził na niego gniew bogów, lecz 
także obdarzył go mianem największego zdrajcy swoich czasów. Użycie konia trojańskiego uczyniło go wiarołomca, lecz chwała po zdobyciu Troi usprawiedliwiła jego czyn. Przez wieki zaś ocena postępku Odyseusza zmieniała się i dziś służy on raczej za przykład przebiegłości i śmiałości niż wiarołomstwa.

Zdrada, a szczególnie ta w wymiarze politycznym, jak widzimy na kilku przedstawionych przykładach, ma ogromną siłę rażenia. Jedna ze starożytnych legend, głosi, że do tyrana Syrakuz Dionizjosa Starszego przybył jego dworzanin Damokles, twierdząc, że król jest najszczęśliwszym człowiekiem na ziemi. Dionizjos, pragnąc unaocznić swój los, zaproponował, by dworzanin przez jeden dzień został władcą. Król pozwolił mu korzystać ze swego łoża i ucztować, jednocześnie kazał, aby na końskim włosiu zawiesić nad dworzaninem ostry miecz. Przerażony Damokles ubłagał Dionizjosa, by ten pozwolił mu odejść. Historia ta doskonale obrazuje sytuację dawnych władców. Miecz wiszacy nad królem jest symbolem zdrady i wciąż czyhającego na niego niebezpieczeństwa. Ciężarowi miecza przeciwstawiona jest kruchość końskiego włosia. Stawką wielkich zdrad najczęściej jest też wielka władza. $Z$ przedstawionego w legendzie obrazu świata jednoznacznie wypływa strach przed zdradą. W czasach kiedy władza była skupiona niemal w jednym ręku, niebezpieczeństwo, jakie niosło wiarołomstwo, mogło mieć katastrofalne skutki. Zagrożony był nie tylko sam władca, ale również jego państwo. $Z$ powodu tego ryzyka wytworzony został $\mathrm{w}$ społeczeństwie obraz, w którym zdrada jest najbardziej potępianym czynem na ziemi, sam wiarołomca zasługuje na najsroższa karę, a dodatkowo jest utożsamiany $z$ opętanym, $z$ szatanem i dopuszcza się aktu $z$ piekła rodem. Dlatego akt zdrady ma aż tak negatywny wydźwięk. Piętnowanie tego zjawiska stało się polityka prewencyjną. Wiarołomca musiał mieć świadomość granicy, która przekracza. We współczesnym świecie władza nie jest już tak mocno skoncentrowana, co minimalizuje możliwość takiego działania. Choć w dalszym ciagu mamy do czynienia $z$ występkami tego typu, to jednak nie pociagaja one już tak radykalnych konsekwencji. 
Podsumowując tę część rozważań, warto podkreślić, że rozległe ramy czasowe publikacji oraz ich popularny charakter wymuszaja na autorach zwięzłość wypowiedzi, a co za tym idzie - selektywność $\mathrm{w}$ przedstawianiu wątków pobocznych. Choć w przypadku pracy Kopra na szczególna uwagę zasługuje wzbogacenie tekstu licznymi ciekawostkami oraz rozprawianie się autora $z$ mitami historycznymi. I tak dowiadujemy się między innymi, że bitwa na Psim Polu prawdopodobnie nie miała miejsca, a podczas obrony Głogowa do machin niemieckich przywiąano jeńców wojennych, a nie tamtejsze dzieci. Lektura przywołanych publikacji pozwala na zapoznanie się $z$ wielowymiarowością aktu zdrady. Czytelnik zainteresowany postaciami wielkich zdrajców powinien pochylić się nad obiema publikacjami. Choć nie sa one wolne od wad, to jako prace o charakterze popularyzatorskim plasują się wysoko w swojej kategorii. Obie książki cechuje przystępny język, a zawiłości historyczne zostaja podane w klarowny sposób. Pozycje te można potraktować jako wstęp do dalszych lektur o historiach wielkich zdrad.

W obu omawianych pozycjach czytelnik niestety nie znajdzie pogłębionej kulturoznawczej czy filozoficznej analizy samego fenomenu zdrady. Choć obaj autorzy przedstawili różnorakie figury zdrajców, to odnoszą się oni wyłącznie do relacji historycznych na ich temat. Czytelnika musi zaś intrygować, czym jest akt zdrady jako taki, jakim semantycznym przemianom podlega jej rozumienie. Postaram się przybliżyć te zagadnienia, odwołując się głównie do postaci Judasza jako archetypu zdrajcy.

$\mathrm{W}$ języku polskim zdrada to przejście na stronę nieprzyjaciela, niedochowanie wierności małżeńskiej czy uczynienie czegoś jawnym. Terminami bliskimi pojęciu zdrady sa wiarołomstwo i odstępstwo. Pierwszy odnosi się do zdrady jako złamania przysięgi, drugi zaś do postępowania odmiennego od przyjętych zasad. W czasach biblijnych za zdradę uważano głównie wyjawienie sekretów, choć 
były nią również niedozwolone praktyki seksualne. Drugi rodzaj zdrady to szczególne zawiedzenie zaufania. W tradycji starotestamentowej za zdradę uważano zarówno zbytnie odsłonięcie ciała, jak i wykorzystanie władzy przeciw komuś. Wydawałoby się, że zdrada Judasza, opisana w Nowym Testamencie, będzie nam bliższa nie tylko kulturowo, ale też pojęciowo. Otóż nic bardziej mylnego. Dlaczego? Odpowiedź na to pytanie pojawi się przy opisie czynu Judasza.

Pośród przywołanych w książce Maya wielkich zdrajców co prawda nie znalazły się postacie mityczne, lecz jak wskazuje we wstępie autor, ich wpływ na postrzeganie póżniejszych bohaterów jest niepodważalny. Prześledzenie mitologicznych wzorców wielkich zdrad oraz ich późniejszych przemian znaczeniowych pozwoli na dokładniejsze scharakteryzowanie problemu zdrady.

Jedna $z$ najstarszych opowieści o zdradzie jest wystapienie Seta przeciw Ozyrysowi. Historia ta zawarta w mitologii egipskiej dotarła do naszych czasów w kilku wersjach, niemniej najobszerniejsza relację odnajdujemy u Plutarcha. Opisuje on Ozyrysa jako dobrego władce oraz założyciela cywilizacji, przeciw któremu knuje młodszy brat - Set. Set zabija Ozyrysa, a ciało jego rozczłonkowuje. Nie godzi się na to siostra, a zarazem żona Ozyrysa Izyda, która zbiera jego członki i składa w jedno, tworząc archetypiczna mumię. Ożywiony Ozyrys staje się królem w świecie zmarłych. Ostatecznie Ozyrys zostaje pomszczony przez Horusa. Badacze zwracaja uwagę, że pierwotnie Set był opisywany jako bóg dobrotliwy, dopiero podczas panowania XXII dynastii (946-722 p.n.e.) Egiptu jego obraz uległ demonizacji. Od tego czasu uznawany jest za bóstwo złe i demoniczne. Dodatkowo na ten okres przypada również działanie proroka Zaratusztry na terenach Persji. Zreformował on ówczesne wierzenia, a jego głównym założeniem była redukcja bóstw do dwóch. Zaratusztra spersonifikował kategorie etyczne i tak bogiem dobrym stał się Ahura Mazda, jego przeciwieństwem zaś, bogiem złym - Angra Mainju. Koncepcja ta stała się podstawa późniejszych doktryn dualistycznych oraz początkiem personifika- 
cji diabła. Jeśli dodamy do tych wierzeń mit grecki opisujący walkę Zeusa, który strącił Tyfona do Tartaru, to odnajdziemy źródła narodzin Szatana w Starym Testamencie. $Z$ łatwością spostrzegamy analogię $\mathrm{w}$ przekazach dotyczacych postępowania najważniejszego spośród aniołów bożych - Szatana. Te stworzone przez Boga jako dobre istoty same $z$ siebie stały się złymi, sprzeciwiły się Bogu, sądzac, że moga być mu równe. Lucyfer wraz ze swoimi stronnikami został pokonany i wygnany $z$ nieba ${ }^{1}$. Ich „upadek” jest efektem wolnego wyboru i „odrzucenia Boga i Jego Królestwa”. Owocem tego buntu jest kolejna wielka zdrada, oto diabeł „ojciec kłamstwa” (J 8,44), kusi w raju prarodziców, obiecując im: „Tak jak Bóg będziecie" ( $\operatorname{Rdz} 3,5 ; 1 \mathrm{~J} 3,8)$. Ewa zachęcona przez węża, który $\mathrm{w}$ tradycji chrześcijańskiej jest utożsamiany $z$ Szatanem, zerwała i skosztowała owoc $z$ drzewa poznania dobra i zła, po czym podała go Adamowi. Wiarołomstwo pierwszych ludzi wobec zakazu Boga sprowadziło na ludzkość grzech pierworodny.

Opowieść o Secie czy bliższa nam kulturowo historia Szatana przedstawiają dualistyczna walkę dobra ze złem. W obu przypadkach zdrada i wiarołomstwo stają się orężem zła przeciwko dobru. To nie brak miłosierdzia Bożego, tylko nieodwracalny charakter wiarołomstwa wobec Boga sprawia, że grzech nie może zostać wybaczony, Święty Jan Damasceński głosi: „Nie ma dla nich skruchy po upadku, jak nie ma skruchy dla ludzi po smierci"2. Te symboliczne wystapienia ustanawiaja zdradę jako narzędzie infernalne, najbardziej podłe i plugawe. Dlatego też każdy, kto posługuje się zdrada, jest utożsamiany $z$ szatanem. I tak $\mathrm{w}$ Ewangelii sam Jezus gani Piotra słowami: „Zejdź mi z oczu, szatanie” (Mt 16,23), gdy ten chce go odwieść od męki. Zatem czy Piotr jest zdrajcą? Otóż taki zarzut w stosunku do pierwszego biskupa chrześcijan wydaje się nadużyciem, lecz Piotr swoim zachowaniem zdradził Jezusa kilkakrotnie, a wiarołomstwem wręcz dorównuje Judaszo-

1 Katechizm Kościoła katolickiego (KKK), Poznań 1994, 391-395.

2 Święty Jan Damasceński, De fide orthodoxa, II, 4: PG 94, 877 C., The Franciscan Institute, 1955; KKK 393. 
wi. Zdaniem badacza Biblii Jamesa Robinsona, to Piotr mógłby zostać wykreowany na zdrajcę Mistrza - wystarczy tylko wspomnieć, że to on gorliwie przysięga chronić Jezusa, a w ogrodzie Getsemani beztrosko zasypia (Mk 14,37), później zaś trzykrotnie wyrzeka się Pana.

A mimo to nie Piotr stał się największym zdrajca ludzkości, lecz Judasz. Według Ewangelii synoptycznych Judasz jest odpowiedzialny za wydanie Jezusa w ręce Sanhedrynu. To on, według relacji Marka, w Getsemani pocałunkiem wskazał swego nauczyciela strażnikom świątynnym.

Jedna $z$ teorii głosi, że alias Judasza miał powstać od transkrypcji słowa scarius $z$ laciny - cząstka sica oznacza sztylet, co wskazywałoby na człowieka uzbrojonego. Według tego tropu Judasz należał do zbrojnego odłamu zelotów zwanego sykariuszami. Było to stronnictwo walczące o wolność Jerozolimy obleganej przez Rzymian. Ze względu na sposób funkcjonowania - działalność podziemną przeciwko władzy oraz sztyletowanie kolaborantów - sykariusze uznani zostali za pierwsza organizację terrorystyczną. Czy u boku Jezusa mógł się znaleźć sykariusz? Wydaje się, że tak, bo skoro mógł tam się znajdować zelota - Szymon Gorliwy (gr. $Z \eta \lambda \omega t \eta \dot{s}$ ) - to nie można wykluczyć również sykariusza. Według Hyama Maccoby'ego, w świetle tej hipotezy cele Jezusa miały być podobne do założeń zelotów. Do organizacji tej należało pięciu $z$ dwunastu uczniów Jezusa. Mają o tym świadczyć ich przydomki: Szymon Gorliwy, Szymon Piotr Barjona, Judasz Iskariota, synowie Zebedeusza Jakub i Jan, zwani Boanerges ${ }^{3}$. Według tej teorii Judasz zdradził Jezusa, kiedy zrozumiał, że zapowiadane przez niego przyjście Królestwa Niebieskiego nie oznacza rzeczywistej walki o wyzwolenie Jerozolimy spod jarzma rzymskiego.

Nie znamy dokładnego powodu zdrady Judasza. Choć powszechnie uważa się, że zdradził on Jezusa dla pieniędzy, wersja ta jest

\footnotetext{
${ }^{3} \mathrm{~W}$ świetle tej hipotezy cele Jezusa były podobne do założeń zelotów. Por. H. Maccoby, Jezus $i$ żydowska walka wyzwoleńcza, przekład A. Skoroszewska, H. Michalak, Ahriman-International, Zgorzelec 1999, s. 120-121.
} 
mało prawdopodobna. Jedynie Mateusz wspomina o tym, że arcykapłani „wyznaczyli mu trzydzieści srebrników” (Mt 26,15). Kwota wydaje się nieprzypadkowa, arcykapłani doskonale znali prawo Tory, a cena, jaka wyznaczyli za Jezusa, ma podwójne znaczenie. $Z$ jednej strony podkreślali, że ich działanie jest zgodne $z$ litera prawa, gdyż powołuja się na Torę. $Z$ drugiej zaś przywołanie Księgi Wyjścia $(21,32)$ podkreśla, że Jezus jest dla nich wart tyle, ile niewolnik. Kwota trzydziestu srebrników była średnią cena, jaka winno się wypłacić za niewolnika ${ }^{4}$.

Podczas gdy Mateusz sugeruje, że przyczyna zdrady była chciwość, to Łukasz i Jan wspominaja, że „szatan wszedł w Judasza” $(\text { Łk 23,3) })^{5}$. Szatan, który wstapił w Judasza, powinien zostać egzorcyzmowany, jak głosi Ewangelia, zarówno Jezus, jak i uczniowie posiadali taka $\operatorname{moc}^{6}$. A więc dlaczego Szatan nie został wygnany $z$ Judasza?

Wszyscy ewangeliści, wspominając ostatnią wieczerzę, podkreślają, że Jezus nie dość, że był świadom zdrady, to jeszcze dokładnie wiedział, kim jest zdrajca. Warto zwrócić uwagę, że kolejny raz to Szatan odpowiedzialny jest ostatecznie za zdradę. Zatem wszędzie tam, gdzie dochodzi do aktów wiarołomstwa, odpowiedzialnościa za nie jest obarczany Szatan jako ich inspirator.

Święty Marek $(3,19)$ na początku swej relacji wymienia skład apostolski, od tego momentu podczas wyliczania dwunastu apostołów Judasz opatrzony jest stałym epitetem „ten, który Go wydał". Bibliści wskazuja, że Judasz na tle pozostałych apostołów

\footnotetext{
${ }_{4} \mathrm{~W}$ czasach Jezusa nie funkcjonowały monety zwane srebrnikami, naukowcy od lat spieraja się, o jakiej walucie jest mowa w Ewangelii. Ponieważ pieniądze zostały odważone ze skarbca świątynnego, oznaczałoby to, że cechowały się wysoka jakością. Prawdopodobnie Judasz otrzymał zapłatę $\mathrm{w}$,tyryjskim srebrze, czyli tetra drachmami, zwanymi przez Żydów "szeklem fenickim". Por. tekst poświęcony dociekaniom nad srebrnikami: R. Wojtaczak, 30 srebrników - problem numizmatyczny, w: J. Sieradzan (red.), Postać Judasza w literaturze, teologii i sztuce, Białystok 2007, s. 186-193; W. Klassen, Judas. Betrayer or Friend of Jesus?, s. 98-99.

5 Por. Mk 14,41-49; Mt 26,47-56; J 18,1-11.

6 Przykładem może być epileptyk (Mk 9,17-29) oraz Maria Magdalena, z której wypędzono aż siedem demonów (Łk 8,1-3). Uczniowie również posiadali taką moc: „Wróciło siedemdziesięciu dwóch, z radością mówiąc: „Panie, przez wzgląd na Twoje imię, nawet złe duchy nam się poddają"” (Łk 10,17).
} 
opisanych w ewangeliach synoptycznych, nie wyróżniał się szczególnie, a jego portret nie pasuje do przyszłego zdrajcy. Jednak zauważalna jest stopniowo dokonująca się demonizacja tej postaci. $Z$ jednej strony, wspomniane wcześniej czyny Piotra sa wybielane, a jego poprzednie zachowania tuszowane, $z$ drugiej zaś strony każda kolejna Ewangelia potęguję wizję Judasza. Apogeum tego zjawiska przypada na relacje Janowa. Jan przypisuje Piotrowi obronę Jezusa w Getsemani, mimo że ewangelie synoptyczne nie podaja tożsamości ucznia, który obciął ucho strażnikowi, a podczas namaszczenia stóp Jezusa przez kobietę, według relacji Marka, znalazły się osoby niezadowolone ze straty tak cennego olejku (Mk 14,3-9). Jan w swojej relacji precyzuje, że osobą tą był Judasz, złodziej i defraudator (J 12,4-6).

Wydana w 1996 roku ksiażka Williama Klassena Judas. Betrayer or Friend of Jesus? głosi jednoznaczną teorię: Judasz nie zdradził Jezusa, lecz wydał go władzom żydowskim, a jego celem była konfrontacja oraz doprowadzenie do oceny roszczeń. Praktyka ta była $\mathrm{w}$ pełni dopuszczalna $\mathrm{w}$ ówczesnym judaizmie ${ }^{7}$. Na poparcie tej teorii badacz argumentuje, że Judasz w Ewangeliach jest tylko

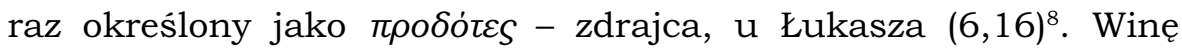
za obecny stan rzeczy ponoszą tłumaczenia, które grecki czasownik

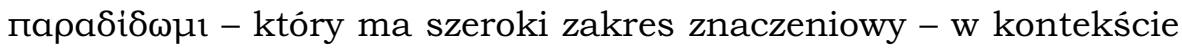
relacji Judasz - Jezus, zawsze tłumaczony jest jako „zdradzić”, choć równie dobrze mogłoby to być „wydać” czy „przekazać”.

Powracamy tutaj do wspomnianej już postaci Judasza jako sykariusza, człowieka, który walczył o wyzwolenie ojczyzny spod rzymskiej okupacji. Możemy przyjąć, że Judasz, rozczarowany postawą swojego Mistrza, wydał go władzom żydowskim, aby przyśpieszyć nadejście Królestwa Niebieskiego i ostatecznego wyzwolenia, wielo-

\footnotetext{
7 W. Klassen, Judas..., s. 47-48.

8 Robinson ten fragment również uważa za pomyłkę. Por. J.M. Robinson, Tajemnica Judasza. Historia niezrozumianego ucznia i jego zaginionej ewangelii, przekład J. Sławik, Media Lazar Nadir, Warszawa 2006, s. 89.

9 H.E. Lona, Judasz Iskariota - Legenda i prawda. Judasz $w$ Ewangeliach $i$ w Ewangelii Judasza, przekład R. Zajączkowski, Wydawnictwo Jedność, Kielce 2008, s. 67.
} 
krotnie obiecywanego przez Jezusa ${ }^{10}$. Teologia chrześcijańska potępia uczynek Judasza, nie zwracając uwagi na to, że bez udziału ofiary Iskarioty nie doszłoby do zmartwychwstania. Zatem Judasz, który zgodził się na udział w boskim planie zbawienia, sam przyjał na siebie krzyż ${ }^{11}$. Według Klassena, był on pośrednikiem między Jezusem a Sanhedrynem, do niego należało nadzorowanie pojmania Jezusa oraz dopilnowanie, by podczas tego wydarzenia nie doszło do rozlewu krwi. Złożony przez Judasza pocałunek również ma wskazywać, że działa on na polecenie Mistrza, oraz manifestować braterska więź między nimi ${ }^{12}$. Pierwszym utworem, w którym zrehabilitowano Judasza, a co więcej, wyniesiono tę postać do rangi bohatera, jest tak zwana Ewangelia Judasza. $Z$ relacji Ireneusza $z$ Lyonu wiemy, że gnostycka sekta kainitów rozpowszechniała ten tekst, wierzyli oni, że to dzięki Judaszowi dokonało się zbawienie. W relacji gnostyckiej Judasz dzięki rozpoznaniu Jezusa zostaje postawiony w bardzo szczególnej sytuacji. Po pierwsze, zaszczytem jest, że to do niego zwrócił się Chrystus o pomoc, po drugie, uczestnictwo w wyzwoleniu ( $\mathrm{z}$ materii) Jezusa nobilituje Iskariotę. W gnostycyzmie bowiem zbawienie możliwe jest nie poprzez śmierć Jezusa, lecz przez pielęgnowanie sekretnej wiedzy, do której dochodzi się drogą oświecenia.

Jak widzimy po przywołaniu tych faktów, zdrada przypisywana Judaszowi nie wydaje się aż tak jednoznaczna, jak się powszechnie uważa. Konsekwentna strategia określania go mianem zdrajcy przyniosła jednak pożądane skutki. Pokłosiem tego stanowiska jest literacki obraz piekła nakreślony przez Dantego Alighieri. Boska Komedia jest synteza średniowiecznej myśli filozoficznej i teologicznej przedstawiająca ówczesna panoramę świata. Umieszczając zdrajców w paszczy Szatana, Dante jednoznacznie nie tylko potwierdza ich winy, lecz przede wszystkim stygmatyzuje sam akt

\footnotetext{
${ }^{10} \mathrm{H}$. Maccoby, Judas Iscariot and the Myth of Jewish evil, Free Press, New York 1992, s. 136; por. J. Sieradzan, Trzy wersje mitu Judasza: współpracownik Jezusa, zdrajca, bóstwo, w: idem (red.), Postać Judasza $w$ literaturze teologii $i$ sztuce, Wydawnictwo Uniwersytetu w Białymstoku, Białystok 2007, s. 13.

${ }_{11}$ Por. ibidem; H. Maccoby, Judas..., 58-59, W. Klassen, Judas..., s. 44-45.

${ }^{12}$ W. Klassen, Judas..., 68-70, 73; J. Sieradzan, Trzy wersje..., s. 13.
} 
zdrady. W najniższym ze wszystkich kręgu dziewiątym, na dnie piekła przedstawianego jako jezioro skute lodem, bestia pożera największych zdrajców ludzkości, a sa nimi: Judasz - zdrajca Jezusa oraz Kasjusz i Brutus - zdrajcy Cezara. Boska Komedia ugruntowuje pozycję Judasza jako zdrajcy oraz potwierdza infernalność samego aktu. Przesłanie biblijne wzmocnione dziełem Dantego skutecznie uprawomocniły obraz Judasz jako zdrajcy. Skalę tego zjawiska przedstawia jedna $z$ konkluzji badań socjologicznych przeprowadzonych kilka lat temu: „Nawet ten, kto już niemal nie wierzy $\mathrm{w}$ nic, wierzy jeszcze, że Judasz wydał Jezusa jego wrogom"13. Spośród badanych aż 91 proc. wierzy, że Judasz zdradził Jezusa, należy jednak zwrócić uwagę, że niektórzy $z$ nich nie wierza w samego Chrystusa ${ }^{14}$. Zatem społeczna percepcja czynu Judasza jest silniejsza niż wiara chrześcijańska. W rezultacie na skutek prowadzenia przez Kościół konsekwentnej stygmatyzacji Judasz stał się zdrajca wzorcowym. W języku polskim imię Iskarioty stanowi synonim zdrajcy, jednak przypisywanie mu etymologicznego spokrewnienia ze słowem ,judzič” jest wtórne. Świadczy to o silnym wpływie samej postaci na postrzeganie rzeczywistości. Ciekawostka jest również fakt, że Judasz jako zdrajca nie mógł nie mieć rudych włosów. Mimo że Ewangelie nie wspominają o jego wyglądzie, to już w XIII wieku ten atrybut towarzyszy na stałe Iskariocie. Od tego czasu rude owłosienie maja kolejni zdrajcy, $z$ Kainem na czele. W Apokalipsie „barwy ognia” sa smoki i konie, które wylicza się jako dzieło Szatana ${ }^{15}$. Zatem sam kolor włosów ma nie tylko stygmatyzować zdrajcę, ale jednocześnie przypominać o jego związku $z$ mocami piekielnymi.

\section{Szymon Bródka}

\footnotetext{
${ }^{13}$ J. Sieradzan, Motyw Judasza w kulturze, w: idem (red.), Postać Judasza..., s. 125.

${ }^{14}$ Ibidem.

${ }^{15}$ Zob. M. Pastoureau, Średniowieczna gra symboli, przekład H. Igalson-Tygielska, Oficyna Naukowa, Warszawa 2006.
}

Szymon Bródka - asystent w Instytucie Studiów Politycznych Polskiej Akademii Nauk. 